\title{
War Grave Excavation Methods: Survey, Results and Suggestions
}

\author{
TÓTH Zsolt ${ }^{1}$
}

\begin{abstract}
War graves, or war heroes' graves, are burial places for soldiers who fell in battle while serving their homeland, or as a result of fighting for their country. War graves around the world are, from time to time, excavated - either by chance or by design - and the earthly remains of the warriors resting within may be exhumed. The following study primarily seeks answers to the questions of who should, in such cases, carry out the excavation of a war grave? Which areas of science may be affected by the excavation? What types of experts can be involved in such instances? And what methods exist for this purpose? A further objective of the study is to make recommendations on the optimal methodology that may be applied by experts in Hungary.
\end{abstract}

\section{Introduction - Definition of the Problem}

As a Hungarian researcher I have faced the problem in my homeland that there is not a unified methodology for excavating war graves. I assume the reason for this may be traced to events in the past.

After the Second World War, due to Soviet influence, unlike the period between the two World Wars, Hungary could not operate its own war graves research and maintenance organisation. The legislative rules stated that the only graves that could be preserved were those of "friendly" soldiers from the Soviet Union and from forces fighting on their side. [1] It is a sad fact how this affected the nation's own war heroes and their relatives. It was forbidden even to visit the final resting places of the "enemy Germans and their henchmen”. In the 1990s, after the change of the socialist state mechanism, the first research could begin on the graves of fallen Hungarian soldiers, both within the country's borders and outside of them. In parallel, data began to be compiled on those foreign soldiers who were buried in Hungary. In the last two decades we have seen a large amount of research related to war graves and a large number of excavations in Hungary. Most frequently these have been carried out by funeral services, without the involvement of experts, and without any type of documentation.

The first step in the process of introducing professional war graves excavation in Hungary was to gain an awareness of the international literature on the subject. It is sufficient to quote one example of the Western European literature on war grave research [2] for us to see how essential it is for excavations to be carried out professionally. One exemplary

1 zsolt.t@citromail.hu, National Heritage Institute, Budapest, Hungary 
precedent in military archaeology is the excavation of the grave of a First World War German soldier, found in 2003. ${ }^{2}$

Studies of the foreign professional literature on war graves research led us to the conclusion that future excavations in Hungary need to be carried out within a framework of scientific research, which makes it necessary to develop a method which is appropriate for local circumstances. In order to achieve this, we set the objectives of learning about and analysing the research procedures of experienced foreign partner organisations, of comparing the different practices, and of evaluating their applicability in Hungary. The most important element was to conduct a survey by sending questionnaires to the competent bodies abroad.

\section{Questionnaire-based survey about war grave excavation methods}

The questionnaire ${ }^{3}$ was sent out to a total of 12 organisations in 11 countries $^{4}$ in the summer of 2011, through the Hungarian office for the preservation of war graves. [22] The survey had a response rate of $50 \%$, because 6 organisations answered the questionnaire. Based on the responses from the war graves research bodies in the Netherlands, Poland, Romania, Germany, Austria and the USA, and in the relevant professional literature, ${ }^{5}$ our analysis could begin.

\section{Existance of competent organisations}

The first question of the questionnaire sent out to the war graves organisations looked for separate focuses on war grave issues. (Is there a separate body or research team in your country which deals with the excavation of war graves? If yes: What is the name of the body and their specific function? If no: Who deals with the exhumation of the remains of war heroes in your country?)

In Austria, war grave excavations may only be conducted with the permission of the Ministry of the Interior, and if necessary, the permission from the country concerned. [3] In justified cases, when permission is granted, Department IV/7 of the Ministry of the Interior notifies the regional office of the Austrian Black Cross foundation in the State concerned,

2 The soldier was buried in his uniform. The crowned Prussian buttons on his jacket were revealing enough in themselves, but the military archaeologists observed that they were arranged on the remains in a twin column. With this fact, it could be established that the jacket was of type "1910 M". The Brandenburg single-column jacket was the one most generally used in the army, but the twin-column Swedish type was only used by the guards regiment. This finding led the researchers to the outcome of this professional excavation: almost a hundred years after the soldier died, he was positively identified as Jakob Hones. If the buttons had been disturbed at the site of the excavation before the military archaeologists could make their observation, it would not have been possible to identify the body.

3 Consisting of 7 sections on the institutes of individual countries which deal with war graves research, and on the work they do.

4 Austria: Österreichisches Schwarzes Kreuz; France: Pôle d’Entretien des Nécropoles Nationales et des Hauts Lieux de Mémoire; Netherlands: Oorlogsgravenstichting; Poland: Rada Ochrony Pamięci Walk i Męczeństwa; Great Britain: The Commonwealth War Graves Commission; Germany: Volksbund Deutsche Kriegsgräberfürsorge e. V. and Deutsche Dienststelle; Italy: Commissariato Generale per le Onoranze ai Caduti in Guerra; Russia: Vojennije Memoriali; Romania: Oficiul Naţional pentru Cultul Eroilor; Ukraine: State Interdepartmental Commission for Perpetuating the Memory of the Victims of War and Political Repressions at the Cabinet of Ministers of Ukraine; USA: Laboratory Director and Forensic Anthropologist The Joint POW/MIA Accounting Command.

5 Example: РУКОВОДСТВО ПО ПОИСКОВЫМ И ЭКСГУМАЦИОННЫМ РАБОТАМ. Москва ТОО “Люкс-арт” 1997. http://may1945bibliotek.narod.ru/eksgumacion01-0.htm (downloaded: 1405 2013) 
which is responsible for coordinating the exhumation. This non-profit organisation has been responsible for war graves throughout Austria, as well as the war graves of Austrian citizens abroad, for more than 80 years. [23]

Since 1919, the German War Graves Agency (in German: Volksbund Deutsche Kriegsgräberfürsorge e. V — VDK) [24] has had the task of researching and preserving the war graves of German soldiers, and in the event of reburial, of exhuming the soldiers' remains. With a staff of 560 people, this is probably the largest war graves preservation body, with the task of maintaining the final resting places of 2.5 million fallen heroes. In order to simplify access to and care of war graves, and the execution of commemorations, one of the principles of the VDK is to re-inter, in central cemeteries, the bodies of German soldiers who were buried in different places. Each region, and each country, employs local experts who are charged with researching and exhuming German soldiers' earthly remains, and with organising their reburial. In the last few decades, 55 mass cemeteries have been built in Eastern, Central and Southern Europe, and 716000 soldiers have been reburied.

The responses gave the following answers: in the Netherlands, the Recovery and Identification Unit of the Royal Netherlands Army (RIU/RNLDA) has the task of researching and excavating the graves of civilian and military war victims, and of identifying the dead. The unit employs three specialists, who work in the laboratory of Camp Soesterberg.

The central body for the preservation of war graves in Poland ${ }^{6}$ does not have a separate research team. The task of the Council for the Protection of Struggle and Martyrdom Sites is, first and foremost, to preserve the memory of war events, sites and role players, which manifests itself mainly in the maintenance and care of war graves and military burial sites. Research into the human remains of war and their excavation falls within the competence of the regional provinces, the Voivodeships. Although there is no central apparatus in Poland for war graves research, investigations are still carried out using scientific procedures. The district attorney of the relevant Voivodeship involves various local scientific bodies in the work. Site research using geo-radar and excavations are carried out by specialist research teams ${ }^{7}$ or by archaeologists from the local universities ${ }^{8}$, anthropological and DNA tests on the remains are conducted by employees of the institutes of forensic medicine in the Voivodeships ${ }^{9}$, and any artefacts or documents found in the graves are examined by museum historians.

In Romania, the National Office for Heroes Memory (ONCE) [25] is the institution which supervises and has the authority to approve the exhumation of the earthly remains of heroes who fell in the Romanian War of Independence, the Balkan Wars and the World Wars. There is, however, no specialist agency to carry out research, excavation and investigations, so this work is done on a case-by-case basis.

The USA has the largest war graves research organisation, not just among the respondents to the questionnaire, but also in the world. The Joint Prisoners of War, Missing in Action Accounting Command (JPAC) [26] is an organisation of more than 400 people, whose main aim is to locate, repatriate and identify the bodies of 83,000 American soldiers around the world, those who never returned from the Second World War, the Korean War, the Vietnam War

6 The Ministry for Cultural and National Heritage oversees the work of the Council for the Protection of Struggle and Martyrdom Sites (Rada Ochrony Pamięci Walk i Męczeństwa, http://www.radaopwim.gov.pl/).

7 Example: Pomorze1945 (http://www.pomorze1945.com/); "Pomost” Society (http://www.pomost.net.pl/)

8 Example: Uniwersytet Mikołaja Kopernika; Kazimierz Wielki University In Bydgoszcz.

9 Example: Department of Forensic Medicine, Pomeranian Medical University, Szczecin. 
and the Cold War. The institution came about in 2003 through the union of several former research institutes with similar missions, and the Command centre is located on the Hawaiian island of Oahu. The organisation operates the Central Identification Laboratory (CIL), which is the largest anthropological laboratory in the world. JPAC has four permanent contingents, located in Thailand, Vietnam, Laos and Hawaii, as well as logistical support teams stationed around the world from Europe to Papua New Guinea. A separate file is opened for each individual case, and a research team is set up to investigate it. In addition to the permanent contingents, JPAC has the capacity to operate 6 research teams at a time, with a staff of 4-9 people. More than 1300 successful identifications have been made so far, and there are currently over 1000 cases in progress.

\section{Affected scientific areas}

The second question focuses on special methods and scientific areas used in identification and reconstruction.

The Austrian war graves foundation involves anthropologists and museologists during exhumations.

In the German agency, the emphasis during war graves research and identification of victims is placed on the historical sciences. The VDK has a database containing biographical data on approximately 860000 war dead, as well as information about their military careers. Additionally, roles in German research may be played by anthropology, odontology and museology.

In order to identify unknown victims, the experts of the Dutch organisation use the scientific methods of a variety of archaeology, anthropology and military history known as battlefield research. The archaeologists and military historians have a thorough knowledge of the military events that took place in Dutch territory, as well as the military uniforms worn and equipment used, and this plays an important role in the research. The anthropologists mainly uses osteological (determining the age and height of victims, and investigating any bone anomalies or traumatic alterations) and odontological (examining the teeth and making odontological maps) methods. The odontological examination can lead to a positive identification if the research team has access to the soldier's dental records. ${ }^{10}$

With regard to the areas of science affected, the leader of one of the Polish research institutes which deals with war graves research, dr. Andrzej Ossowski, professor at the Pomeranian Medical University, Szczecin (Pomorski Uniwersytet Medyczny w Szczecinie), and an expert in judicial genetics and personal identification, gave his response to our question. He informed us that war grave research in Poland combines the methods of the historical sciences, forensic medicine, (military) archaeology and criminology. Probably the most important condition in achieving a successful outcome of the research is the research team itself, which needs to include the following experts: 1 . anthropologist, 2 . forensic geneticist (these two positions are often filled by a single person), 3. military historian, 4. military uniform and equipment specialist, 5. criminologist, 6 . expert in electronic devices. The professor also adds that other essential qualities are a passion for this type of activity and commitment. Some members of research teams in Poland are often volunteers.

10 During the World Wars of the 20th century, American and German forces, for example, made dental records of their soldiers. Unfortunately this was not the practice everywhere, and so this method cannot be applied in the case of research into Hungarian soldiers. 
Colleagues at the Romanian institute conduct excavations using historiological, archaeological, anthropological and — as indicated in their letter to us - military and health procedures. There are no anthropological experts within the Romanian war graves organisation, but those taking part in the excavations examine bones in situ, in search for traumatic alterations.

The scientific work process of JPAC commences with the activities of historians. These are the people who constantly are collating data from veterans, families, special reports, archives and other documentary sources. Archive photographs are examined by a special photographic historian. If the historians uncover enough data to investigate a case, with the possibility of finding the earthly remains of a missing soldier, JPAC sets up a research team depending on the nature of the task, with members that may include a historian, an anthropologist (or taphonomist), a bomb disposal expert, a geologist, a spatial informatics specialist, a linguist, a forensic photographer and a technician. Technicians are involved in special situations, for example when excavating a crashed aircraft. If required, underwater archaeologists may also be called on to participate in the work. Any "material evidence" found in the vicinity of the earthly remains is examined by the archaeologists of JPAC in an attempt at making an identification.

\section{Methodologies, auxiliary materials, publications}

Three questions in the survey were about the written support materials, methodology descriptions and publications that the partner organisations are aware of in connection with the field of war graves research.

From the response received from Austria, we learnt that exhumations conducted there basically begin with the excavation of the skeleton's legs. Austrian experts also place a high priority on the material relics recovered from war graves.

In Germany, the VDK conduct excavations of war graves on the basis of methodological instructions which are issued centrally. Work proceeds in line with the following main stages:

- acquisition of all the permits required for the excavation;

- notification of the local authorities;

- review of the historical documents and lists of losses for the area concerned;

- estimation of the number of dead located there;

- determination of burial site numbers (if they exist);

- determination of the direction in which the bodies lie;

- involvement of employees; survey of the burial site;

- estimation of the depth at which the bodies are buried;

- construction of a fence around the excavation site;

- start of documentation; photographs before work starts;

- removal of plants and the topsoil; manual recovery of bones, continuously photographed;

- placing the bones in exhumation coffins;

- full excavation of the graves;

- filling the holes and restoring the environment;

- photography after work is completed; handing back the area;

- writing reports;

- placing the coffins in a temporary location at the end of each working day. 
The reburial registers completed during the excavation and the objects used for identification are sent, when the work is completed, to the central office of the organisation in Berlin. The information received there is analysed and compared with historical documents and reports on losses. After the objects have been examined, identification can be made using identification markings and personal effects (such as rings with engravings) if any are found, or on the basis of individual physical characteristics (such as bone deformities or dental imprints).

The Dutch researchers recommended the publication titled Battlefield Archaeology [4], as well as a few works within the body of literature on anthropology, which are described as essential. [5] In addition to traditional anthropological and odontological examinations, the RIU/RNLDA also uses DNA analysis and three-dimensional facial reconstructions. The Dutch experts also belong to a vast system of connections, with members consisting of war graves preservation partner organisations, military corps, museums, justice organisations and historians. The work of war graves research is often carried out with the involvement of this circle of professionals.

Professor Dr. Andrzej Ossowski informed us that in Poland, the field work is prepared by historical research. This includes a review of the documents in the local archives and the parish registries, and in some cases also consists of interviews with surviving eyewitnesses of wartime events. Obtaining maps from the time of the events and from the present day, and making aerial and satellite photographs, are also part of the preparatory phase, and this contributes greatly to the success of the research. When all the documents and maps are available to the researcher, these are analysed and interpreted. The next stage of the process, which is the start of field work to locate war burial sites, is conducted on the basis of the analysis. The fieldwork is conducted with the use of GPS devices, metal detectors and magnetometers. After a burial site is identified, the dimensions of the grave are recorded, and then the human remains are excavated using archaeological methods. When excavating a war grave, however, it is important to uncover the bones as quickly as possible, so the process could be called "quasi-archaeological”. During the careful excavation, special attention must be paid to any relics which could help in identifying the people concerned, such as identification markings (“dogtags”), documents and personal effects. Every such find must be carefully rescued and recorded. Following the excavation of the skeleton, the in-situ anthropological tests take place, and a sample is taken for later DNA tests. In Poland there is an increasing number of scientific articles being published on the subject of war graves research. [6] One of the most important publications on this subject, also published in the English language [7], presents the research methods used during the excavation of the land around a former concentration camp. More than 600000 Jewish prisoners were killed in the death camp at Belzec. One of the main objectives of the research was to find human remains. The work was complicated by the fact that the majority of victims' bodies had been burnt in crematoria. Excavations at the approximately 6 hectare site were prepared for by making a thorough study of written documents and site plans, as well as a summary of witness testimonies. Ground-penetrating radar $^{11}$ and pilot digs were used to locate relics during the research. In 1997-1998 a total of 2227 soil samples were taken at five-metre intervals over a network which covered the whole area, with their precise locations meticulously recorded on a site plan at a scale of 1:100. The samples were submitted to archaeological analysis, and the structure of the soil could then

11 Pürckhauer type sampling auger. It is $65 \mathrm{~mm}$ in diameter, and can be used for depths of $6-8 \mathrm{~m}$. 
be accurately determined. A total of 225 samples contained evidence of a grave — such as human teeth, hair or bone fragments, traces of mortuary wax ${ }^{12}$ or ashes of cremated bodies — at depths ranging from $1.7 \mathrm{~m}$ to $5 \mathrm{~m}$. [8: 73] By tracing the origins of these samples back to their positions on the map, the locations of mass graves were identified. Following this, archaeological methods were used to pinpoint the limits of the graves and to excavate them. With this method, a total of 33 mass graves were identified in Belzec.

In Romania, ONCE has formulated a methodology which is followed when carrying out excavations, research and reburials. [9] It distinguishes between three different types of war grave.

The precise location of human remains is known. In type 1, the methodology starts from the premise that based on the grave markings; an attempt will be made to identify the location of the pelvic bone of the war dead. This bone is large enough to be found relatively easily, and is therefore the simplest from with which to determine the position in which the skeleton is lying. During excavations, archaeopedology, that is the archaeological study of soils, is also applied.

Only the approximate area of burial is known, and the war grave is unmarked. In type 2 war graves, pilot digs are recorded on a site map, with the aim of finding the first grave, which can later be used as the basis for comparisons.

There is no knowledge about the location of the war grave. A different procedure is used for each of the above cases. In type 3 war graves, pilot digs are also carried out, similarly to those in type 2, with the aim of finding graves in the supposed area of burial by progressing along two opposed diagonals. The methodology extends particularly to phenomena which can be used by the researcher to determine the presence of multiple graves or mass graves. The description covers traces of traumatic alterations that may be observed on the bone, which can be used to determine the cause of death. It also issues a warning that at this stage of the excavation; the grave may only be excavated by hand, using small tools, such as a small rake, to reduce the chance of damage to any relics. The grave must be thoroughly examined until all artefacts have been found by the researchers. Following this, the bone fragments may be raised one by one, and placed in plastic bags, with the place and time of the exhumation clearly indicated on them. Those taking part in the excavation must make an accurate record of the bones. Because of the risk of oxidation, the material remains are quickly placed in an environment which is protected from air and sunlight, and are transferred to the museum of military history for examination. The methodology also describes how bones and teeth can be used to work out the age of the victim at the time of their death, and other anthropological methods for determining their gender. It also contains a basic description of craniometrical techniques. Later it describes the methods of making an inventory of bones and the rules for storing and reburying the remains, in line with the principles of criminalistics.

The American research teams conduct their work using a variety of rules and supplementary materials. JPAC operates in accordance with defined political principles and with high expectations for ethics, professionalism and conduct. For example, according to principle no.

12 Grave wax or mortuary wax (adipocere) is a fatty substance derived essentially from the saponification of a mixture of ammonium, potassium and limestone salts with fatty acids (especially palmic acid). It is formed particularly in environments where the muscles and soft tissues of corpses have lain for many years in moist clay soils or water. All the soft part are transformed into this wax-like mass, which usually preserves the form of the tissues and organs. Source: Pallas Nagylexikon (http://www.kislexikon.hu/hullaviasz.html (downloaded: 0202 2013) 
4, colleagues must carry out the highest level of scientific work to provide forensic service of exceptional quality. This requires the following conditions: competency, continuous training, acquiring experience, familiarity with laboratory procedures, professional development and the application of known scientific protocols and methodologies. The tasks of JPAC and their implementation are described in detail in their operating rules. [10] These define the mission of the institution, and the operations relating to research and investigation, laboratory procedures and identification. The operations and working methods of the CIL are regulated separately [11], and the methodologies are defined in supplementary laboratory manuals. [12] Additionally, the employees of the Command also have at their disposal a range of scientific publications and auxiliary materials [13], and databases for example, on the places where American troops served and missing persons. Due to restrictions of space, this study cannot make a thorough exploration of the American methods for every branch of science, but it is nevertheless useful to highlight at least one basic procedure. During in situ examinations, the historian and the linguist have the important function of garnering as much information as possible about past events from the local population. A good example of the importance of the method of questioning is shown by the research carried out by JPAC and their predecessor organisation in Yeong San, Korea. ${ }^{13}$ The bodies of American soldiers killed in fighting in the area - during battles fought by Manchu troops - were not all found by researchers. Research carried out half a century later, however, led to success, when members of JPAC learnt from an elderly local person that after the fighting, the local residents had buried the bodies themselves. As the researchers in the 1950s had not used the method of questioning - merely searching for victims on the battlefield, when locals had taken them elsewhere for burial — it was impossible for them to be successful. [14]

\section{Bone remains after excavation}

The next question in the survey was concerned with the fate of the remains after exhumation.

German soldiers are reburied with honours, with the cooperation of the local representative of the VDK, in the closest German military cemetery to the scene of the excavation, generally during a special commemoration. Reburials are governed by strict rules. [15]

The Dutch team informed us that the bone remains of war victims are always subjected to anthropological tests. When the victims were soldiers, they are reinterred in a heroes' burial garden with military honours. ${ }^{14}$

The war graves research team in the Voivodeship of Pomerania in Poland has already excavated a huge number of soldiers' graves from World War II, numbering some 3000. As a result of professional excavations and the anthropological and genetic tests that are carried out on the bodies, around 1000 of the war dead have been identified.

In Romania, the reburial of excavated war heroes is governed by law. [16] The bone remains are reburied in exhumation coffins, measuring $60 \times 40 \times 20 \mathrm{~cm}$, and made of cardboard or wood. If the religion of the victim is known, they are accorded the appropriate funeral ceremony, and if not, they are laid to rest in accordance with the rites of the Romanian Orthodox

13 AGRS - American Graves Registration Service

14 Dutch soldiers are reburied in the Grebbeberg or Loenen Military Cemeteries, British soldiers in one of the burial gardens maintained by the GWGC, such as the Military Cemetery in Arnhem-Oosterberg, and German soldiers are buried in the Military Cemetery in Ysselsteyn. 
Church. If more than one soldier is reburied, their coffins are not placed in separate graves, but side by side in a common grave. The soldier is finally given a new war grave marking, in accordance with their religion. [17]

The slogan "Leave no man behind", used by the US military forces, also extends to fallen American soldiers. In various parts of the world, JPAC not only researches the earthly remains of American soldiers, but repatriates them in every case. When members of the research team find the bones of a missing soldier, they are sent for examination, along with any relics found nearby, to the CIL, where thorough forensic tests are carried out by the laboratory's scientists. In the laboratory, forensic anthropologists and odontologists attempt to reconstruct the skeleton, and to determine the origin of the victim, their gender, their age at the time of death, the cause of death and any traumatic alterations or illnesses, from all this the victim's biological profile is put together. The main aim is to establish the identity of the soldier. The laboratory is equipped with a high level of technology, and is capable of conducting DNA sampling, nuclear and mitochondrial DNA analysis, scanning electron-microscopic and radiological tests, and thin-section bone histological examinations. Personal identification is assisted by computer programs which have been specially developed by JPAC. One such program compares the dental records of soldiers with the dental finds from the burial site. A further aid to personal identification may be provided by a database containing the results of optical tests, which is particularly useful if eyewear is recovered from the grave. When the laboratory tests have been carried out, JPAC hands over the remains of every American soldier to the American Battle Monuments Commission [27], which has the responsibility for re-interment of the soldier. Unless the relatives specify differently, the USA reburies their war dead with military honours in the central military garden of rest at the Arlington National Cemetery near Washington DC.

\section{Documentation/ Record methods}

The final question in the survey concerned the types of documentation produced during war graves research.

In Austria a separate file is created for collecting the documents generated during the excavation of a war grave: lists of the bones and the soldier's objects (uniform remnants, indications of rank, medals and insignia).

The VDK makes a record of all the information uncovered during a war grave excavation, and register visual phenomena and artefacts. As far as documentation is concerned, it is probably the German agency which makes the most complete set of documents. This is also indicated by the remarkable amount of material which is attached to the reburial documentation that is prepared during every excavation. The documentation contains the following:

- a printed registration form;

- a list of the artefacts found;

- data on the property where the excavation took place;

- map and site plan;

- plan of the grave(s);

- photographic documentation of the condition before, during and after the excavation;

- certificate verifying the restoration of the site after the end of the work;

- archive and other relevant documentation. 
Data uncovered during the excavation are recorded on a form, known as the reburial register. The compilers of the form have provided space for recording all the important information - such as the site of the exhumation, details of the victim, objects found in the grave, data about the people taking part in the excavation — but it is also possible to mark the recovered bone and tooth remains on anthropological and odontological maps.

The Dutch researchers exhume human remains using archaeological methods, during which the stages of the process are photographed. The GPS coordinates are also recorded, along with the compass points of the grave and its dimensions. An investigative report is made for every excavation, which is sent, in the case of foreign soldiers, to the competent partner organisation and the relevant embassy.

Generalising from the example of the research team named Pomorze $1945^{15}$, it can be stated that the process of excavation work in Poland is documented by photographing the work, making an identification report, and preparing a site map and a list of relics found.

In Romania, ONCE workers complete a form during every excavation, which records the following details: the location of the exhumation, the location of the new grave, lists of the bones and objects that were recovered, the place where they are stored, and other observations, and if it is possible to establish any of them the form also records the gender and height of the victim, and their name and the regiment they were in.

The experts at JPAC open a separate "missing in action" file for every individual case. Scientists from the different fields summarise the data, and document in detail the observed phenomena and the results of the test they have carried out. In order to remain objective, however, the persons carrying out the tests have no knowledge of the other details of the case. All the data and documents generated during the work process are placed in the file, including reports by historians, archaeologists, forensic experts and all other experts involved in the case. After all the test results have been included in the file, the scientific director of JPAC evaluates the case before closing it.

\section{Summary and comparison of the presented procedures}

Based on the above, we will attempt first to summarise the types of war grave research bodies according to the way they are organised. This concerns the principles under which they operate, the types of experts they employ, the particular methods that the experts apply, the way they record their results, the places where the personal identification of the war dead is carried out and where the soldiers are reburied. In order to simplify the analysis of the knowledge received so far the table below summarises a few important elements of the data presented.

15 The excavations carried out by the Pomorze 1945 research team can be traced back on their homepage: http:// pomorze1945.com/?co=117\&lang=PL (downloaded: 1205 2013) 


\begin{tabular}{|c|c|c|c|c|c|c|}
\hline & $\begin{array}{l}\text { War graves } \\
\text { research body }\end{array}$ & Mission & Experts & Special method elements & Documentation & $\begin{array}{c}\text { Non-field } \\
\text { research sites }\end{array}$ \\
\hline Netherlands & $\begin{array}{l}\text { central state } \\
\text { research team (3 } \\
\text { persons) }\end{array}$ & $\begin{array}{l}\text { Researching and } \\
\text { identifying war dead, } \\
\text { and reburial in a } \\
\text { central cemetery }\end{array}$ & $\begin{array}{l}\text { archaeologist, } \\
\text { anthropologist } \\
\text { (osteological and } \\
\text { odontological), military } \\
\text { historian (battlefield } \\
\text { researcher!) }\end{array}$ & $\begin{array}{l}\text { battlefield research, DNA analysis, } \\
\text { facial reconstruction, } \\
\text { odontological mapping, system of } \\
\text { contacts }\end{array}$ & $\begin{array}{l}\text { photos, data about location (GPS } \\
\text { co-ordinates) and the grave }\end{array}$ & own laboratory \\
\hline Poland & \begin{tabular}{|l|} 
no dedicated \\
research team - \\
local researchers \\
and institutes are \\
commissioned for \\
each case
\end{tabular} & $\begin{array}{l}\text { case work - } \\
\text { identification and } \\
\text { reburial of war dead }\end{array}$ & $\begin{array}{l}\text { historian, } \\
\text { archaeologist, } \\
\text { geneticist, museologist, } \\
\text { criminologist, } \\
\text { technician }\end{array}$ & $\begin{array}{l}\text { thorough preparation, "almost } \\
\text { archaeological excavation", in-situ } \\
\text { anthropological tests, DNA } \\
\text { samples, soil samples }\end{array}$ & $\begin{array}{l}\text { photos, records, site plans, list of } \\
\text { finds }\end{array}$ & $\begin{array}{l}\text { universities, } \\
\text { justice research } \\
\text { institutes }\end{array}$ \\
\hline Romania & \begin{tabular}{|l|} 
no dedicated \\
research team- \\
experts \\
commissioned for \\
each case
\end{tabular} & $\begin{array}{l}\text { case work-reburial } \\
\text { of war dead }\end{array}$ & $\begin{array}{l}\text { specially trained } \\
\text { experts who perform } \\
\text { multidisciplinary tasks }\end{array}$ & $\begin{array}{l}\text { special procedures for identifying } \\
\text { grave sites, excavation begins with } \\
\text { pelvis }\end{array}$ & $\begin{array}{l}\text { records with data on sites and } \\
\text { graves, list of finds with place of } \\
\text { storage, data on war dead }\end{array}$ & $\begin{array}{l}\text { no data } \\
\text { available }\end{array}$ \\
\hline Austria & \begin{tabular}{|l|} 
non-profit \\
regional body \\
employees and \\
commissioned \\
experts
\end{tabular} & no data available & $\begin{array}{l}\text { anthropologist, } \\
\text { museologist }\end{array}$ & excavation begins with leg bones & records, list of finds & $\begin{array}{l}\text { no data } \\
\text { available }\end{array}$ \\
\hline Germany & $\begin{array}{l}\text { non-profit } \\
\text { regional body } \\
\text { research team and } \\
\text { commissioned } \\
\text { experts }\end{array}$ & $\begin{array}{l}\text { reburial of fallen } \\
\text { German soldiers in } \\
\text { national central } \\
\text { burial grounds for } \\
\text { each region }\end{array}$ & $\begin{array}{l}\text { historian, } \\
\text { anthropologist, } \\
\text { odontologist, } \\
\text { museologist, specially } \\
\text { trained expert who } \\
\text { perform } \\
\text { multidisciplinary tasks }\end{array}$ & $\begin{array}{l}\text { comprehensive documentation, } \\
\text { mainly subsequent examinations, } \\
\text { greatemphasis on historiological } \\
\text { methods }\end{array}$ & $\begin{array}{l}\text { documents: records, list of finds, } \\
\text { site data, maps, site plans, } \\
\text { photos, certificates, permits, } \\
\text { historical documents; in the } \\
\text { reburial records data on the } \\
\text { victim, the site, the grave, the } \\
\text { circumstances, participants in } \\
\text { the exhumation; includes } \\
\text { anthropological and } \\
\text { odontological mapping }\end{array}$ & own laboratory \\
\hline USA & $\begin{array}{l}\text { central, state } \\
\text { research } \\
\text { commission, } \\
\text { permanent } \\
\text { divisions and } \\
\text { research teams } \\
\text { (400 people) }\end{array}$ & $\begin{array}{l}\text { to repatriate every } \\
\text { fallen soldier to the } \\
\text { USA, carry out } \\
\text { identification in the } \\
\text { USA and then rebury } \\
\text { them in the central } \\
\text { national cemetery }\end{array}$ & $\begin{array}{l}\text { historian, } \\
\text { archaeologist, } \\
\text { anthropologist (or } \\
\text { taphonomist), } \\
\text { odontologist, bomb } \\
\text { disposal expert, } \\
\text { geologist, spatial } \\
\text { informatics specialist, } \\
\text { linguist, forensic } \\
\text { photographer, } \\
\text { technician }\end{array}$ & $\begin{array}{l}\text { extremely broad multidisciplinary } \\
\text { methods, thorough preparatory } \\
\text { work, extremely thorough lab tests: } \\
\text { e.g. modern DNA analysis, } \\
\text { radiological and osteological tests; } \\
\text { dental and optical records } \\
\text { databases }\end{array}$ & $\begin{array}{l}\text { "missing in action" files: all } \\
\text { potentially related data is } \\
\text { recorded, along with expert } \\
\text { opinions and research results }\end{array}$ & own laboratory \\
\hline
\end{tabular}

The presentation of the 6 war grave research bodies that submitted responses and their methods builds up a comparative picture from which we can draw some general conclusions. Countries with larger populations and with stronger economic potential not only maintain organisations which deal with the preservation of war graves, but are also able to operate separate war grave research and excavation teams and identification laboratories. The best example of this is the United States of America, whose JPAC organisation embodies the most professional variant of institutional war grave research. Outside the closed set of countries that participated in the survey, we can also state that, in addition to the USA and Germany, Great Britain and Russia also maintain war grave preservation and research organisations with large numbers of employees, which supports this general conclusion. Other countries in a favourable economic position, or which do not have significant numbers of unknown war heroes, or war heroes whose final resting places are unknown, have organisations operating with a smaller apparatus, but still with high level technical conditions. In these cases, however, the application of scientific methods cannot be described as fully comprehensive. In states which do not have the material resources to operate a separate research institute for their war dead, the excavation of war graves and the identification of soldiers are carried out in different ways, but these states are also capable of dealing with these issues in a professional manner. Preconditions for this, however, are political will and well considered and prepared organisational work. Based on the above, countries may be classified into three categories depending on their war grave research organisations: 
TÓTH Zsolt: War Grave Excavation Methods: Survey, Results and Suggestions

1. those with permanent war grave research institutions (e.g.: USA-JPAC; Germany VDK);

2. those with permanent war grave research offices (e.g.: Netherlands — RIU/RNLDA);

3. those which engage war grave research teams on a case-by-case basis (e.g.: Poland, Romania, Austria).

The efforts individual countries make related to war graves research is also closely linked to economic factors. The principle taken by the USA, whereby every single fallen soldier is researched and repatriated, is something that only a few countries can afford. It is also possible to classify the procedures into three categories, depending on the principles they operate under:

1. the "No one left behind" model: The aim is to research and excavate the graves of all fallen soldiers, and to repatriate and rebury their earthly remains (e.g.: USA);

2. the "We care for everybody" model: The aim is to research and excavate the graves of fallen soldiers, and to rebury their earthly remains in the closest national military cemetery (e.g.: Germany);

3. the "We won't let it be destroyed" model: There is no planned permanent research, and the aim is not to centralise war graves, but to rebury the earthly remains of soldiers whose graves are in danger, or are uncovered by chance, in the closest military cemetery or in the local cemetery (e.g.: Romania).

From the preceding chapters and the table we can see the types of experts used by the competent bodies during the work processes carried out in different countries. It is possible to refer to a type of institution that employs specially trained staff who are capable of carrying out work in more than one branch of science at the same time. This type includes the example of ONCE in Romania, which has an employee who is both a historian and an anthropologist. On the other hand, there is a type of institution that employs a separate expert for every branch of science involved in the procedure. Common denominators here are the historian, the archaeologist and the anthropologist. In addition to these, there are numerous independent sciences or branches of science which may be represented by experts in the field of war graves research.

The particular methods of each field of the sciences are applied, if not identically, then at least similarly by the different organisations. There may be differences when, in addition to the basic fields of science in war graves research, namely historical science, archaeology and anthropology, additional branches of science are also applied in the research. With regard to the conduct of the procedures, however, a definite division may be drawn. A distinction must be made between the work processes used during well-prepared research work and those followed subsequently when a war grave is excavated by chance. These can be summarised according to the components set forth below, and the order in which they occur.

1. prepared war graves research: military historical examination $\rightarrow$ field research $\rightarrow$ excavation $\rightarrow$ museological, anthropological and genetic tests $\rightarrow$ summary and analysis of results $\rightarrow$ military historical examination (e.g.: USA, Germany);

2. unprepared war graves research: excavation $\rightarrow$ museological, anthropological and genetic tests $\rightarrow$ military historical examination $\rightarrow$ summary and analysis of results $\rightarrow$ military historical examination (e.g.: Austria, Romania).

The second procedure omits the field research, and its first military historical examination is carried out not as a precondition to the work process, but as a consequence of it. 
Concerning the documentation of research work there are no differences of principle between the different states, and all of them consider it important. There are, though, some differences regarding the amount of data recorded and the different formulas.

Exhumed soldiers - regardless of whether they are successfully identified or not — must be laid in their final resting place. As regards the location of the reburial, there are also three categories into which the organisations may be classified: the reburials may be described as central, regional or local:

1. central: In this case the earthly remains of soldiers are reburied in a central national military cemetery (e.g.: USA, Netherlands);

2. regional: In this case the earthly remains of the fallen are reburied in the closest national military mass cemetery (e.g.: Germany);

3. local: In this case, soldiers are laid to rest in the same place, or in the nearest cemetery (e.g.: Romania).

This all presents us with an overall picture of the nature and operations of war grave research organisations. With this knowledge in mind, we can venture at an adaptation of the organisations and methods to the circumstances in Hungary.

\section{Recommendation for a new method - a potential model for Hungary}

Although Hungary does not yet have a regulated formula for carrying out war graves research, several attempts have already been made to implement one which is based on science. The Hungarian body with responsibility for preservation of war graves, which has changed its name on several occasions, operated in the early 2000s in the Institute and Museum of Military History. In the bastion of Hungarian military historical research, the first professional work came about as a co-production of the office for war graves preservation and the department of military archaeology, and following some reorganisation the work was continued from the Ministry of Defence. Representatives from the two departments travelled to many locations, during excavations, to try out the methods borrowed from other branches of science or read about in foreign professional literature, and to formulate new methods with the aim of reconstructing historical military events and identifying the war heroes. At the same time, the civil sphere also recognised the importance of researching and preserving war graves, and an abundance of societies, foundations and scientific groups were formed and are working hard for the common goal. [18] Following the initial attempts made with the knowledge of the major English language textbooks and publications on the subject [19], a new method needs to be developed, based on a knowledge of the methods used by foreign partner organisations, and adapted to be suitable for local conditions, and after it has been successfully tested, the new method needs to be launched.

Due to the fact that, even today, it is not uncommon for human remains of soldiers to turn up in Hungarian soil, it would be extremely useful to operate a permanent war graves research institute or office, functioning either as a separate organisation working closely with the Ministry of Defence Institute and Museum of Military History and the Ministry of Defence Department for the Preservation of Military Traditions and War Graves, or as a part of one of them. As for the composition of the research team, I consider it essential, on the basis of international experience, to use the "triumvirate" of a military historian, an archaeologist and 
an anthropologist when war graves are excavated. A three-person team of this kind would be an engine driving war graves research in Hungary, and would carry out both the prepared and the occasional (unprepared) types of work. During the process, every single excavation site would be accorded a collection of documents, containing the following attachments:

- exhumation register;

- list of material artefacts;

- site plan;

- photographs of the excavation;

- expert opinions by the museologist and the anthropologist;

- related military historical descriptions and sources;

- maps;

- reburial data sheet;

- photographs of the reburial.

These tasks could also be carried out without the presence of one or other experts, but in such an event the research would fail to include numerous investigative reports, and this could encumber the realisation of certain goals, such as personal identification. The Hungarian Army would provide a bomb disposal expert to join the research team if the circumstances require. The principle of war graves research, based on the economic clout of the country, would only stretch as far as the "We care for everybody" model. It would have the aim of researching and excavating the graves of fallen war heroes, and of reburying them in the closest national military cemetery. It would be possible to introduce and provide a central military cemetery in Hungary for Hungarian soldiers (and for those of unknown origin), as well as other central Hungarian military cemeteries in individual foreign countries. ${ }^{16}$ If and when a central military cemetery is established, the research team would also assume responsibility for transferring human remains there, but until this situation arises, it will be necessary to involve local funeral services in carrying out reburials locally. The three-person research team would represent only the core of the organisation, and the headcount would need to be expanded, either for functional tasks or for professional tasks. As a temporary measure, until it is possible to set up a professional research team, we recommend the creation of an internet website, based on the Dutch model, which experts from the different fields (historians, archaeologists, anthropologists, archivists, amateur researchers, etc.) in Hungary would be invited to participate in. This would provide an opportunity for information to be shared and processed, for contacts to be made, and, if the situation arises, for "locally competent" experts to undertake excavation and investigation work, under the coordination of the Ministry of Defence. In my experience, the involvement and cooperation of enthusiastic researchers would throw up plenty of opportunities.

\section{Afterword}

The recommended method described above, which is based on the international professional literature and on the survey, is currently undergoing testing. In recent years the Ministry of Defence and other independent researchers have made efforts to implement scientifically based research in this area. Most recently, the method was used during an excavation that 
took place close to the city of Szolnok on 26th July 2012, which is presumed to be a mass war grave from the autumn of 1944. A positive sign for the future is given by the fact that scientific issues [20] and articles [21] on this subject are now being written by Hungarians. One of the main objectives of the research carried out by the author of these lines is to develop a Hungarian step-by-step methodology for war graves research - an article with greater detail than this study - which could lay the groundwork for future requirements in this field of research. It is our hope that the establishment of a Hungarian research team and the application of a unified methodology will produce great results in a variety of scientific branches. Furthermore by setting up central cemeteries, a contribution may be made towards bringing a final closure to the destructive World Wars of the Twentieth Century, as "the war is only over when the last war hero has been buried."

\section{References}

[1] In Hungary, this was regulated by Act XIX of 1947 (on the reverent preservation of SovietRussian military monuments and war heroes' graves).

[2] FRASER, A.: Finding Jakob. In. COOKSEY, J. (Ed.): Battlefields Annual Review. (pp. 2941). Barnsley: Pen \& Sword Military, 2005; SAUNDERS, N. J.: op. cit. pp. 98-137; ROBERTSHAW, A., KENYON, D.: Digging the Trenches. The Archaeology of the Western Front. (pp. 174-181). Barnsley: Pen \& Sword Military, 2008.

[3] 1948/07/07 BGBl No. 175/176

[4] LYNCH, T., COOKSEY, J.: Battlefield Archaeology. Stroud: Tempus Publishing, 2007.

[5] BASS, W. M.: Human osteology: a laboratory and field manual. Missouri: Missouri Archaeological Society, 1987.; ROBERTS, C., MANCHESTER, K.: The Archaeology of Disease. Ithaca: Cornell University Press, 2007.; MANN, R. W., HUNT, D. R.: Photographical Regional Atlas of Bone Disease. Springfield: Charles C. Thomas Publisher, 2005.; THOMPSON, T., BLACK, S.: Forensic Human Identification: An Introduction. New York: Taylor \& Francis, 2006. DOI: https://doi.org/10.1201/9781420005714

[6] OSSOWSKI, A., PIATEK, J., BRZEZIŃSKI, P., ZIELIŃSKA, G., PARAFINIUK, M.: Identification of the site of skeletal remains from World War II. Arch Med Sadowej Kryminol, 593 (2009), 243-7; OSSOWSKI, A., BRZEZIŃSKI, P., PIĄTEK, J., POTOCKA-BANAŚ, B., JANUS, T., JAŁOWIŃSKA, K., PARAFINIUK, M.: The use of search techniques employing ground-penetrating radar in forensic medicine. Problems of Forensic Sciences 2011. LXXXVII. 253-263.

[7] KOLA, A.: Belzec. The Nazi Camp for Jews in the light of archaeological sources. Excavations 1997-1999, The Council for the Protection of Memory and Martyrdom/United States Holocaust Memorial Museum, Warsaw/Washington 2000.

[8] MATTOGNO, C.: Belzec in Propaganda, Testimonies, Archaeological Research, and History. Chicago: Theses \& Dissertations Press, 2004.

[9] Instructioni privind executarea lucrarilor de exhumare. http://once.ro/PROCEDURA\%20 EXHUMARII.pdf (downloaded: 1205 2013)

[10] JPAC Standard Operating Procedure 2011.

[11] ISO/IEC 17025:2005; ASCLD/LAB-International Supplemental Requirements for the Accreditation of Forensic Science Testing Laboratories 2011.

[12] JPAC Laboratory Manual 2009. 
[13] ADAMS, B. J.: Establishing personal identification based on specific patterns of missing, filled, and unrestored teeth. Journal of Forensic Sciences, 48 487-496.; ADAMS, B. J.: The diversity of adult dental patterns in the United States and the implications for personal identification. Journal of Forensic Sciences, 48 497-503.; ADAMS, B. J., MAVES, R. C.: Radiographic identification using the clavicle of an individual missing from the Vietnam conflict. Journal of Forensic Sciences, 47 369-373. ; BASS, W. M.: Osteology: A Laboratory and Field Manual. 5th Edition. Columbia: Special Publication No. 2 of the Missouri Archaeological Society; BENEDIX, D. C.: Differentiation of Fragmented Bone from Southeast Asia: The Histological Evidence. PhD Dissertation. Knoxville: University of Tennessee, 2004.; BERG, G. E., COLLINS, R.: Personal identification based on prescription eyewear. Journal of Forensic Sciences, 52 406-411.; BROTHWELL, D. R.: Digging up Bones. 3rd Edition. Ithaca: Cornell University Press, 1981.; CONNOR, M., SCOTT, D. D.: Metal detector use in archaeology: An introduction. Historical Archaeology, 32 76-85.; McCORMICK-GOODHART, M. H.: On the Cold Storage of Photographic Materials in a Conventional Freezer Using the Critical Moisture Indicator (CMI) Packaging Method. www.wilhelm-research.com/subzero/cmi.html (downloaded: 21 10 2013)

[14] SILVERSTEIN J., BYRD, J., OTINEU, L.: Hill 209: The Last Stand of Operation Manchu, Korea. In. SCOTT, D., BABITS. L., HAECKER, C. (Eds.): Fields of Conflict (pp. 417-428). London: Praeger Security International, 2007.

[15] Burial instructions for the reburial of German war dead in Eastern Europe. Kassel, 1998. B-WH/Ma.

[16] Act no. 379/2003.

[17] Gov. Dec. no. 635/2004.

[18] BEDÉCS Gy.: Az első világháború emlékezete Galíciában, az Isonzó-völgyében és a Doberdón. (Memoirs from the First World War in Galicia, the Isonzo valley and the Doberdó.) Győr: Totem Kiadó, 2008.

[19] ROBERTSHAW, A., KENYON, D.: Digging the Trenches. The Archaeology of the Western Front. Barnsley: Pen \& Sword Military, 2008.; POLLARD, T., BANKS, I. (Eds.): Bastions and Barbwire. Studies in the Archeology of Conflict. Leiden, Boston, 2009.; COOKSEY, J. (Ed.): Battlefields Annual Review. Barnsley: Pen\&Sword, 2005.; WARNOCK, B.: The Dead of Winter. How battlefield investigators. WWII veterans, and forensic scientist solved the mystery of the Bulge's lost soldiers. New York: Chamberlain Bros., 2005.; FIORATO, V., BOYLSTON, A., KNÜSEL, C. (Eds.): Blood red roses: the archaeology of a mass grave from the battle of Towton ad 1461. Oxford: Oxbow Books, 2000.; BROTHWELL, D. R.: Digging up Bones. The Excavation, Treatment, and Study Of Human Skeletal Remains. Ithaca: Cornell University Press, 1981.; SCOTT, D. D., CONNOR, M. A.: They Died With Custer: Soldiers'Bones from the Battle of the Little Bighorn. Norman: University of Oklahoma Press, 2002.; BROWN, M. OSGOOD, R.: Digging Up Plugstreet: The Western Front Unearthed. Sparkford: Haynes Publishing Group, 2009.; OSGOOD, R.: The unknown warrior. The archaeology of the common soldier. Stroud: Sutton Publishers, 2006.; WHITFORD, T., POLLARD, T.: For Duty Done: A WWI Military Medallion Recovered from the Mass Grave Site at Fromelles, Northern France. Journal of Conflict Archaeology, 5 1 (2009), 201-229. DOI: https://doi.org/10.1163/157407709X12634580640533

[20] NÉGYESI L.: Csaták néma tanúi. A csata-és hadszíntérkutatás — hadtörténeti régészet fogalma és módszerei. (The silent witnesses of battles. Battlefield research - the concept and methods of military historical archaeology). Budapest: HM Hadtörténeti Intézet és Múzeum (Ministry of Defence Institute and Museum of Military History), 2010.; TÓTH Zs. (Ed.): Hőseink nyomában. Budapest: Zrínyi Kiadó, 2013.

[21] TÓTH Zs.: Az eljárás ismertetése hadisírok előkerülésekor. (A description of the procedure to be followed when war graves are discovered.) Rendészeti Szemle, 58 (04 2010), 147-159.; Ibid: Bukowna (Bukivna) hősei és a M. Kir. 49 Honvéd Gyalogezred. (The Heroes 
of Bukowna (Bukivna) and the 49th Infantry of the Royal Hungarian Army.) Honvédségi Szemle, 65 (01 2011), 52-58.

[22] HONVÉDELMI MINISZTÉRIUM (Hungarian Ministry of Defence), Társadalmi Kapcsolatok és Hadisírgondozó Hivatal (Office of Social Relations and the Preservation of War Graves); current body: Honvédelmi Minisztérium, Társadalmi Kapcsolatok és Háborús Kegyeleti Főosztály (Ministry of Defence, Public Relations and War Memorial Service Department). http://www.hadisir.hu/ (downloaded: 3012 2013)

[23] Österreichischen Schwarzen Kreuzes, Kriegsgräberfürsorge. http://www.osk.at (downloaded: 1406 2013)

[24] Volksbund Deutsche Kriegsgräberfürsorge e. V. http://www.volksbund.de/ (downloaded: 12 06 2013)

[25] Oficiul Naţional pentru Cultul Eroilor. http://www.once.ro/ (downloaded: 1306 2013)

[26] The Joint POW/MIA Accounting Command. http://www.jpac.pacom.mil/ (downloaded: 23 05 2013)

[27] American Battle Monuments Commission. www.abmc.gov (downloaded: 0406 2013) 